Artigo

\title{
Uma sociologia da compreensão a partir do par crítica e jocosidade
}

\author{
A sociology of comprehension based on \\ critics and jocularity
}

\author{
Alexandre Werneck*
}

\begin{abstract}
Resumo: O objetivo deste artigo é analisar o papel desempenhado pela compreensão nas situações críticas, a partir de momentos nos quais a jocosidade seja o elemento central da crítica. Para tanto, o texto entrecruza duas pesquisas nas quais o humor serve como forma de operacionalizar a crítica: 1) observações nas ruas de dois bairros do Rio de Janeiro em busca da operacionalização da crítica por meio de dispositivos de jocosidade, o que produz modulação da crítica; e 2) grupos focais com estudantes a respeito de cartazes jocosos das manifestações políticas de 2013 no Brasil, analisando críticas baseadas na ridicularização pela ironia. Estuda-se, então, como os atores compreendem (ou não) uns aos outros na definição das situações em que se inserem e o papel da ideia de compreensão, isto é, da contemplação dos quadros de referência abstratos do outro, nessas situações. Depreendem-se três dimensões da compreensão de elementos situacionais a partir desses signos: cognitiva, contextual e moral.
\end{abstract}

Palavras-chave: Compreensão. Crítica. Jocosidade. Efetivação. Moral.

\begin{abstract}
The aim of this paper is to analyze the role of comprehension in critical situations, by means of the observation of moments in which jocularity is the central element of criticism. Therefore, the text intersects two investigations in which humor serves as a way to put the critics in operation: 1) observations in the streets of two neighborhoods of Rio de Janeiro in search of deployment of criticism through jocularity devices, which produces modulation of criticism; and 2) focus groups with students about joking posters of 2013 political manifestation in Brazil, focusing on criticism based on reducing to ridicule by irony. I analyze how the actors comprehend (or not) each other in defining the situations in which they are in and the role played in such situations by the idea of comprehension, that is, the recognition of the abstract frameworks of the other. Here, we perceive three dimensions of comprehension of situational elements based on these signs: cognitive, contextual and moral.
\end{abstract}

Keywords: Comprehension. Critic jocularity. Effectuation. Morality

\footnotetext{
*Doutor em sociologia pelo PPG em Sociologia e Antropologia (PPGSA), da Universidade Federal do Rio de Janeiro (UFRJ, Rio de Janeiro, Brasil), professor do Departamento de Sociologia da UFRJ e do PPGSA/UFRJ <av.werneck@uol.com.br>. Este artigo traz resultados do projeto de pesquisa "Violências moduladas: gramáticas e dispositivos da crítica e da negociação na conflitualidade urbana no Rio de Janeiro", coordenado por mim e financiado pela Fundação Carlos Chagas Filho de Amparo à Pesquisa do Estado do Rio de Janeiro (Faperj), por meio de seu Edital de Pesquisa Básica (Processo E26/110.327/2014). Agradeço aos colegas Mariana Cavalcanti, Eugênia Motta e Cesar Teixeira por observações em diferentes momentos da escrita do texto.
}

Civitas, Porto Alegre, v. 16, n. 3, p. 482-503, jul.-set. 2016 


\section{Introdução}

Estamos em uma via de pedestres no centro do Rio de Janeiro. Nela, um artista de rua faz cotidianamente uma apresentação: mímico, ele segue os passantes, fazendo-se de "sombra", mimetizando seus movimentos, posicionando-se a distância mínima e tentando prever seus passos imediatos para imitá-los. É uma brincadeira estabelecida no local, já que o homem trabalha ali há 20 anos, de segunda a sexta-feira, de $12 \mathrm{~h}$ às $14 \mathrm{~h}$. Os recorrentes já conhecem sua arte, seu chapéu de pescador, sua camisa de listras horizontais, a bermuda com suspensórios, as luvas brancas (com que aperta as mãos dos que o descobrem a segui-los) e sobretudo seu rosto pintado de branco. É como um palhaço, mudo, que transforma em gracejo a maneira como nos movemos ali. Os habitués já desenvolveram seus métodos para não serem seguidos - já que isso costuma associar à "vítima" uma condição de tolo, de ludibriável, de "mané", como se diz nas ruas da cidade. Justifica-se: ser pego por Marivaldo - o nome não é fictício - é ser apresentado aos outros por meio de gestos expressivos, clown, por vezes exagerados, sublinhando os trejeitos mais característicos de cada um como se fossem uma caricatura. $\mathrm{O}$ "sombra" sempre exacerba uma passada característica, um gesto marcante, uma forma de se apressar ou de se estar tranquilo e o reexibe em tempo real, enquanto o traço se apresenta. Somos, assim, "unidades móveis" (Goffman, 1971) que se expressam, involuntariamente, na forma de se mover. E essa forma singulariza. Se for percebida, o que nosso artista justamente faz: ele lança holofotes sobre o que é invisível, inescrutável, mas digno de nota. E como ele exagera nossos gestos, eles surgem na dimensão de cacoete, de estranheza, excentricidade, de, em certo sentido, defeito. De modo que a mímica é uma espécie de "zoação" (Werneck, 2015), uma espécie de crítica.

Um dia, o artista está lá, produzindo sua obra, e se põe a seguir um passante. De terno e gravada, o homem carrega uma pasta com a mão esquerda e fala ao celular com a direita. Absorto, caminha pelo calçadão, alheio ao restante do mundo. Passada levemente apressada, responde ao telefone com gestos do outro braço, erguendo levemente a pasta a cada alteração da voz, como se sua mão tivesse soluços. Prato cheio, então, para Marivaldo, ele é seguido, em toda a riqueza de sua coreografia social. Mas não são nem dez passos: o mímico recebe como resposta a seu trabalho uma cotovelada do braço direito de seu modelo. Por pouco seu rosto não é acertado, já que ele desvia em uma fração de segundo e tropica, indo ao chão.

- Vai zoar a puta que te pariu, filho da puta! - diz o engravatado, rompendo o silêncio de um ambiente de rua lotado de sons, mas que se altera diante de uma mudança de tom de voz. 
Mas a resposta com o cotovelo não é de todo inesperada. Como Marivaldo bem sabe, nem todo mundo aceita, gosta, de ser objeto de caricatura. Fala o mímico:

- Tem gente que não tem esportiva, que não entende que a gente está fazendo uma homenagem - para, ao ser provocado sobre o caráter crítico de sua reverência: - Toda brincadeira aponta o que o outro tem de estranho, mas ser estranho é lindo.

Pois a reação do passante de terno é um momento importante das interações sociais. Trata-se da chegada ao uso da força física em uma situação que a princípio seria de convite a uma sociabilidade alegre, lúdica, a zoação, que mostrei (Werneck, 2015) ser recorrente nas situações urbanas do Rio de Janeiro. Uma parcela importante dessa fenomenologia, então, diz respeito aos momentos em que essa sociabilidade é justamente ameaçada pela "violência" e exatamente por esses dispositivos de jocosidade: são consistentes ruídos de comunicação, de impossibilidade de compreensão da situação estabelecida pelo outro.

O objetivo deste artigo é analisar o papel desempenhado nas situações críticas pela compreensão, isto é, pela contemplação dos quadros de referência morais do outro. Para tanto, o texto se baseia no cruzamento de duas pesquisas relacionadas à operacionalização da crítica por meio de um mesmo elemento, a jocosidade: ${ }^{1}$ 1) a observação nas ruas de dois bairros do Rio de Janeiro em busca da operacionalização de dispositivos morais de jocosidade que se utilizam de elementos com formato de crítica para sua efetivação - campo descrito em maiores detalhes em trabalho anterior (Werneck, 2015); e 2) a realização de grupos focais com estudantes a respeito de cartazes jocosos levados às manifestações políticas de 2013 (as chamadas "jornadas de junho") no Brasil e do uso do humor na política. ${ }^{2}$ A ênfase em elementos jocosos permitiu isolar a crítica em uma situação limite, enfatizando uma operação retórica relevante em termos críticos: tornar o oponente do conflito algo "sem seriedade", direcionando a operação crítica também para seus limites compreensivos. Como esses dois tipos de situação são de potencial de conflito, a mobilização de casos em que se lança mão do humor na crítica permitiu observar duas dimensões específicas ligadas ao tema de como os atores compreendem (ou não) uns aos outros: por um lado, momentos em que a crítica é tornada implícita, ao passar por modulação, operada em zoações

\footnotetext{
${ }^{1}$ Para uma revisão bibliográfica sobre os estudos sobre a jocosidade, ver Werneck (2015, p. 190-192).

${ }^{2}$ Galeria que foi objeto de levantamento em várias fontes e é analisada mais detidamente em outro texto (Werneck e Gorini, 2016).
} 
(Werneck, 2015); por outro, momentos em que ela é explicitada, por meio da ridicularização, operada pela ironia (Hutcheon, 1995; Colebrook, 2004).

A crítica pode ser percebida como um dos elementos centrais da vida social quando é lida sob o prisma da mútua observação valorativa entre dois atores, entendidos como "agentes competentes" (Garfinkel, 1967), isto é, a partir do pressuposto de que tomamos conta das ações uns dos outros e as julgamos segundo quadros de referência morais (Weber, 1947[1922]; Wright Mills, 1940; Boltanski e Thévenot, 1991). A sequência desse modelamento resulta em uma ênfase nas operações de accountability social (Austin, 1979 [1956-1957]; Scott e Lyman, 2008 [1968]; Goffman, 1971), por um lado, e, por outro, de manifestação dos elementos das insatisfações, isto é, as críticas e suas provas e comprovações (Boltanski e Thévenot, 1991; Boltanski, 2009). A ideia aqui, então, é estudar como se constrói uma economia da crítica - a operação de apresentação de insatisfação/desagrado em relação ao que se vê no mundo na qual se articulem ao mesmo tempo a vontade dos atores de imaginar/propor um mundo diferente daquele que os insatisfaz e a necessidade de a vida seguir seu curso sem mudanças bruscas capazes de comprometer as possibilidades de controle sobre ela - isto é, sem abalar substancialmente as bases da rotina. Essa economia parece pender entre a ideia de direcionar os trilhos para um destino melhor e aquela de que não se pode parar o trem, apresentando aos atores sociais o constante desafio de modulação do diálogo entre suas utopias - mobilizadas por meio da "capacidade moral" e da "capacidade crítica" (Boltanski e Thévenot, 1991; 1999) - e seu reconhecimento do caráter situado de vários elementos da vida - trazidos à tona pelo que chamei (Werneck, 2012, p. 274-278; 313-316) de "capacidade metapragmática", isto é

uma capacidade para se dar conta [...] de que há uma distância digna de nota entre as metafísicas morais que orientam a utopia das ações sociais e os mundos que por meio delas se constituem e, mais que isso, entre esse próprio duo cités/mundos [...] e aquilo diante do que eles se constituem, o mundo, a vida prática, as situações pragmaticamente constituídas e os estados assumidos pelos participantes dessas situações (Werneck, 2012, p. 274).

A pesquisa de observação de rua foi realizada ao longo de dois anos e meio em dois bairros da cidade do Rio de Janeiro: Campo Grande (na Zona Oeste) e Centro. Em ambos, foram realizadas incursões etnográficas por ruas e espaços públicos e privados relativos ao comércio e ao transporte. A permanência longa e frequente nesses locais permitiu observar as situações de mobilização da jocosidade e seu uso crítico (Werneck, 2015). A pesquisa 
com os grupos focais reuniu cinco conjuntos (de diferentes tamanhos) de estudantes do ensino superior de três universidades cariocas, uma pública e duas privadas, de cursos de ciências humanas. ${ }^{3}$ Ao todo, foram ouvidas 59 pessoas. Nos grupos, falava-se de como os participantes se manifestaram (ou não), como eles viam a possibilidade de isso ser feito por meio do humor e como o fariam. Era projetada uma seleta de imagens de cartazes jocosos reunidos por outra etapa da pesquisa. ${ }^{4}$ Estimulados a analisar esses cartazes, os participantes emitiam suas opiniões e apresentavam suas interpretações para as piadas críticas e as críticas jocosas contidas nos mesmos. A observação nos grupos permitiu analisar de perto como os atores compreendem diferentes formas de crítica.

Assim, por um lado, as situações apresentadas na pesquisa 1 demonstram a possibilidade de o conteúdo da crítica circular sem a necessidade de uma ruptura da rotina proporcionada pelo que Boltanski e Thévenot (1991) chamam de "momento crítico", cujo nome, como sublinham "faz referência ao mesmo tempo à atividade crítica das pessoas e à raridade dos momentos de crise" (Boltanski e Thévenot, 1999, p. 359). Por outro lado, as situações reunidas na pesquisa 2 permitiram acessar várias dimensões semióticas das situações de apresentação de críticas. Essa análise baseada em diferentes campos resultou na possibilidade de traçar um eixo transversal através das formas como a crítica impele os atores a um imperativo de compreensão (Weber, 1947 [1922]) - seja no exercício da própria crítica seja na contemplação dos vários virtuais envolvidos no par mundo criticado x mundo utópico/imaginado - e como esse imperativo se manifesta de várias formas e em várias dimensões.

Para compor esse quadro, esta análise privilegia algumas opções analíticas. A primeira delas diz respeito a se pensar a crítica na clave da questão da efetividade das participações dos atores (críticos) na "definição de situação" (Thomas, 1969 [1923]). Essa opção, no entanto, em vez de se limitar a tratar a capacidade crítica como mero índice da agência das pessoas (Sztompka, 2014; Ritzer e Gindoff, 2014), privilegiará a observação da actância dos entes envolvidos nos momentos situados. Com isso, em vez de uma discussão sobre capacidade decisória e intencionalidade - o que estaria no centro do palco ao se falar em agência social -, estamos aqui no horizonte de uma discussão sobre como os "actantes" (Greimas, 1966; Latour, 1997 [1987]) - encarados em uma ordem semiótica (Peirce, 1998 [1893]) - efetivamente determinam as

\footnotetext{
${ }^{3}$ A escolha dos estudantes se deu por conta da faixa etária habitual (mais jovem) e da presença maciça dessa categoria nas manifestações das chamadas "jornadas de junho" (Gohn, 2014).

${ }^{4}$ Ao todo foram reunidos 117 cartazes, que foram tipificados e são analisados em Werneck e Gorini (2016).
} 
situações (Werneck, 2014) nas quais assumem estados de grandeza (Boltanski e Thévenot, 1991). Trata-se, então, de um trânsito da análise, deslocando sua ênfase dos elementos decisórios para os elementos decisivos.

Uma segunda opção diz respeito ao deslocamento de um modelo de sociologia da ação para um de sociologia da situação, movimento que consiste em tomar como assunto da accountability social não simplesmente as ações praticadas pelos atores, mas sim as situações por eles definidas. O pressuposto dessa versão mais pragmatista do "situacionismo metodológico" (Cicourel, 1964; Knorr-Cetina, 1981; Collins, 1981; Joseph, 1984) está no cruzamento da perspectiva clássica de William I. Thomas - e sua máxima de que "se os homens definem situações como reais, elas são reais em suas consequências" (Thomas e Thomas, 1938 [1928], p. 572) - e a perspectiva do modelo das economias das grandezas (EG) de Boltanski e Thévenot (1991, p. 11), com a ideia de que situações são definições de estados (situados) ocupados por pessoas e coisas (ambos tratados como actantes), estados diferenciais esses que definem por sua vez grandezas, constituindo as situações como enquadramentos em uma economia destas. Assim, enfatizar a análise situacional significa dizer que o que os atores avaliam em suas "indagações valorativas" (Scott e Lyman, 2008[1967], p. 140) - isto é, suas críticas e questionamentos - são menos as ações que enxergam objetivamente e mais as situações que definem ao mesmo tempo experiencialmente e em suas operações interpretativas. Críticas, desculpas (Werneck, 2012) e justificações, então, são, nesse enquadramento, dispositivos de efetivação não (simplesmente) de ações, e sim de situações.

Outra opção diz respeito ao uso do termo efetivação, que, como tenho proposto (Werneck, 2012): a ideia passa pela busca de uma máxima orientação pragmática, a partir da constatação das consequências dos atos das pessoas e das configurações situacionais. Efetivar algo é demonstrar que isso produz consequências, efeitos, e as bases sobre as quais isso se dá. O conceito, então, opera outra forma de indagação valorativa, não a respeito da legitimidade (que, afinal, é circunscrita à questão da justiça, no final das contas mais uma entre outras possibilidades), mas à pura possibilidade de definição da situação: a efetividade é uma forma mais abstrata das próprias ideias de competência e conveniência (Boltanski, 1990; Thévenot, 1990; Werneck, 2012). Ela advém da premência da constatação de que se algo ocorreu é porque podia ocorrer, o que pode ser percebido apenas por meio das consequências produzidas por essa ocorrência mesma. Assim, é por meio da observação das consequências produzidas pelas configurações estabelecidas em uma situação que se pode fazer um mapeamento dos elementos de sua definição (Thomas e Thomas, 1938 [1928]). É por meio de uma pergunta sobre a geração dessas consequências 
que se pode compreender como as situações se efetivam. De modo que a análise contida neste texto pretende estudar as formas de efetivação de tipos específicos de situação, em cuja definição a crítica ocupe o papel central, seja por circular de forma explícita, seja por flutuar de maneira modulada.

Mas a principal opção analítica aqui é a ênfase empírica depositada em um dos elementos centrais da definição das situações pelos atores - isto é, a maneira como eles percebem a distribuição de grandezas e seus fundamentos e como projetam e efetivam suas formas de lidar com essas configurações situadas: a compreensão. A forma como o problema da actância se apresentará aqui diz respeito ao fato de essa definição de situação depender de um conjunto de práticas de interpretação, que não pode ser considerada uma operação semiótica e cognitiva puramente individual, baseada estritamente na capacidade de cada um de ler signos. Ela precisa ser pensada, antes disso, como operação social de compreensão (Weber, 1947 [1922]), isto é, de percepção de outros mundos possíveis, a serem traduzidos comparativamente a nossas visões de mundo, e tomados como abstrações efetiváveis a partir da accountability social. Nesse diapasão, a crítica adquire um sentido peculiar, o de convite à (ou demanda de) prestação de contas - isto é, à oferta de sentido (Weber, 1947; Werneck, 2014) - e isso demanda que se lance uma luz especial sobre aquilo que chamei de forma-crítica (Werneck, 2015), a forma formal segundo a qual tem lugar a manifestação de insatisfação baseada em julgamento valorativo, isto é, seu protocolo, seu como-fazer. Com essa abordagem, essa forma deixa de ser pensada como uma regra normativa e passa a ser entendida como uma espécie de guia para tornar os atores competentes para criativamente (Joas, 1996) se entenderem - ainda que para entender os termos do conflito entre eles.

\section{De uma sociologia compreensiva a uma sociologia da compreensão}

A reflexão de Max Weber sobre a compreensão (Verstehen) impele a meditar em um triplo registro: de um lado epistemológico; de outro sociológico; de outro ainda, moral. No primeiro, estamos diante da ideia de que os homens inevitavelmente valoram aquilo com que se deparam no mundo e que os cientistas, como quaisquer homens, também o fazem (Garfinkel, 1967). E isso torna necessário, a fim de manter a objetividade do conhecimento científico (Weber, 2001 [1904]), conceber um metavalor capaz de se sobrepor a quaisquer outros, justamente a compreensão, a ideia de que, na análise, não se valora o que é analisado, ao se adotar como questão analítica e substrato empírico justamente a forma como os atores valoram. Assim, a verstehende Soziologie se fundamenta em uma perspectiva sobre o próprio social: a base 
da convivência entre os homens passa a ser a demanda de demonstração das bases de valores usadas para fundamentar as ações sociais, donde ela se torna basicamente uma sociologia do conteúdo capaz de preencher essas ações, seu espírito (Geist), seu sentido (Sinn), apresentado por meio de uma fenomenologia dos motivos (Motive/Gründe). E disso decorre finalmente que não apenas a sociologia se volta para a moral como questão fundamental, como também o social depende de um elemento primordialmente moral: a disposição para compreender (Pelz, 1974). E “compreender" será o entendimento do fato de as ações/estados situacionais dos outros terem os seus motivos, isto é, seus sentidos per se, seus próprios quadros de referência de efetivação, de modo que a compreensão se torna um fenômeno mais do que cognitivo. Afinal, se tomarmos a definição de ação social de Weber (1947 [1922], p. 88), que considera ser aquela que "em virtude do sentido subjetivo a ela atrelado pelo agente (ou agentes), leva em conta [grifo meu] os comportamentos dos outros e é consequentemente orientado em relação a eles" e a forma como Wright Mills (1940) interpela essa definição pragmaticamente, podemos fazer uma extrapolação situacionista e pensar que os estados ocupados pelos atores são eles também sociais por dependerem, para sua efetivação, de levar em conta os estados dos outros. Isso confere ao ato de compreender um papel primordial na vida social, uma vez que é sempre preciso ter no horizonte $o$ que preenche o estado ocupado pelo outro. E, nesse sentido, uma crítica passa a poder ser interpretada como uma fenomenologia de tradução/interpretação. Como mostrei anteriormente (Werneck, 2012, p. 62-69), criticar é fazer uso do dispositivo responsabilidade, isto é, a obrigação social - em geral tácita de os atores responderem pelo que fazem, de modo que a crítica se torna uma demanda por essas respostas, as prestações de contas (accounts), constituindo um imperativo dessa operação. ${ }^{5}$ Ora, se a crítica, nessa lógica, pede ao outro que se explique, isso significa que ela está disposta a ouvir, isto é, buscar compreender os motivos - e os quadros de referência abstratos - capazes de sustentar os estados situados. Essa versão acordável, accountable (Werneck e Loretti, 2016), portanto, diferente de sua parente mais próxima, sua forma radical, a acusação, que simplifica essa complexidade moral ao limite para, de posse de um único quadro de referência, tomado como obrigatório, exigir a punição do outro (Misse e Werneck, 2012; McEvoy, 1995, p. 17), afirmando a impossibilidade de compreensão.

\footnotetext{
${ }_{5}^{5}$ Para Boltanski e Thévenot (1991), essa configuração diz respeito a um imperativo de justificação, mas sugiro que ele seja pensado mais amplamente comum imperativo de prestação de contas.
} 
O espaço da crítica é, assim, um terreno da Verstehen e o movimento aqui proposto pretende, então, isolar a compreensão no ponto final dessa equação, mas sem ignorar seus termos anteriores, que lhe servem de fundamento: trata-se de adotar a compreensão como objeto, como fenômeno a ser problematizado, tendo em mente que ela demanda constantes operações de tradução (Cardoso de Oliveira, 2014).

\section{Pressupostos: ainda sobre a forma-piada e a forma-crítica}

Previamente (Werneck, 2015), apresentei os elementos constitutivos das duas formas formais centrais para este debate: a forma-crítica e a forma-piada. A ideia central daquele e deste trabalho é que a jocosidade, essa característica de uma forma de agir centrada no gracejo, tem na crítica um componente privilegiado - e que o inverso é muitíssimo recorrente. Como mostramos eu e outros autores (Werneck, 2015; Davies, 2011; Raskin, 2008; Billig, 2005), uma das maneiras mais recorrentes e efetivas - e atualmente mais populares - de se fazer graça é apontar o "defeito" de algo, isto é, aquilo que isso teria de estranho, bizarro, errado, criticável. ${ }^{6} \mathrm{E}$ com essa ideia em mente, é fácil enxergar a participação de cada uma das duas formas na outra: pode-se fazer piada usando elementos constitutivos da crítica e se pode igualmente fazer a crítica circular por meio de dispositivos jocosos. Em ambos os casos, é de uma operação moral que estamos falando: os atores manifestam discursivamente - de forma falada/escrita ou não, afinal se pode discursar agindo tanto quanto se pode agir discursando (Austin, 1975) - julgamentos de elementos que consideram em desacordo com um princípio abstrato de administração do bem (Werneck, 2012).

Pois então, como já mostrei (Werneck, 2015), a forma-crítica corresponde a um protocolo dos elementos necessários para se efetivar uma crítica, aquele evento no qual tem lugar uma manifestação de discordância, chamando-se atenção para uma diferença de posições entre os envolvidos. Por sua vez, a forma-piada é construída em torno de um protocolo segundo o qual se produza um enunciado voltado para a chamada punchline, uma fala ou ocorrência que altera e subverte a lógica (em uma descrição ou enunciação) ou o fluxo dos acontecimentos (em uma narrativa) de uma situação e, com isso, induziria ao riso. Entrevistas realizadas com humoristas profissionais e a observação de manuais de humor - por exemplo, Vorhaus (1994), Carter (2001), Kaplan $(2013)^{7}$ - permitiram depreender um protocolo bastante efetivo nessa forma, estruturado da seguinte maneira:

\footnotetext{
${ }^{6}$ Inclusive ao se apontar para si mesmo, uma das ferramentas mais habituais do humor.

${ }^{7}$ Este é um pequeno exemplo de uma galeria de 30 manuais que analisamos.
} 
1. Situação (setup): Apresentação do conjunto de elementos. É a parcela que estabelece a expectativa e o conjunto de dispositivos em torno do qual se constrói logicamente a piada.

2. Virada (punch): É a parcela que estabelece a mudança na situação que produzirá o efeito humorístico. “[P] ode ser cúmplice, previsível (como no humor de bordão, em que é mobilizada uma frase/ação que o observador sabe que será dita/feita), ou enigmática (como no caso do humor de esquetes, em que situações são criadas e é no caráter surpreendente da virada que se constitui o humor). Pode ser física, verbal, estrutural, abstrata etc.” (Werneck, 2015, p. 199).

\section{A compreensão a partir da incompreensão: as bases da rotina por meio de sua ruptura}

Para dar conta da maneira como a compreensão se distende como prática e como processo, parto aqui de momentos em que ela seja falha, em que não seja possível entender o outro, a fim de explicitar justamente seus elementos. Esses momentos dizem respeito a quando o uso da jocosidade é o protagonista da incompreensão.

\section{Compreensão falha 1: fazendo o mímico falar ou na mímica, fala-se pelos cotovelos}

De volta a Marivaldo, o "não ter esportiva" mobilizado pelo mímico remete a uma ideia importante para se pensar a vida nas ruas de uma cidade. É que ter esportiva é algo que se cobra aos derrotados, aqueles que deveriam "saber perder", que deveriam entender que "o importante é competir". E isso sugere à forma-piada uma dimensão atlética, lúdica: o esporte ali é passar incólume sem ser "pego" pelo mímico. O objetivo da brincadeira ${ }^{8}$ é conseguir driblá-lo. A questão é que nessa brincadeira se entra involuntariamente, já que o palhaço não pergunta à pessoa se ela quer participar. Mas há uma expressão corrente nas ruas do Rio: "Não quer brincar, não desce pro play". A ideia contida nessa frase diz respeito inicialmente ao fato de que, se alguém entra em um setting jocoso (o "playground"), é preciso ser capaz de sustentar a "partida" até suas últimas consequências. Há, no entanto, outra dimensão central disso decorrente: é que as regras desse esporte estariam estabelecidas e difundidas e todos precisariam conhecê-las. Andar pelas ruas do Rio seria estar sempre "inscrito" para tomar parte, seria estar sempre "no play". Sempre

\footnotetext{
${ }^{8}$ Para uma discussão sobre brincadeira em uma outra geometria, mas em diálogo com a aqui utilizada, ver Comerford (1999).
} 
se poderá ser alvo de zoação e é preciso estar pronto para isso. E, ao mesmo tempo, deve-se estar sempre pronto para uma reação.

Possibilidade real a ser encarada: todo momento de mobilização de jocosidade pode se tornar uma situação em que o humor, ao ser considerado desrespeito, seja respondido com força desproporcional. Se, em um quadro de "regimes de ação" (Boltanski, 1990), a jocosidade se mostra um importante dispositivo de manutenção da justesse (ao mesmo tempo que faz circular a crítica), ela evidentemente pode também se tornar objeto de cada um dos outros regimes: pode virar alvo de questionamento no regime de justiça, uma vez que ela própria possa se converter naquilo que esteja em questão - ao se invocar, por exemplo, a crítica de que a zoação não é uma ação adequada para aquela hora ou local, para aquele contexto, ou que se esteja "zoando demais", exagerando nas tintas da piada etc.; pode ser enquadrada no regime de ágape, já que a pilheria levará à comprovação da amizade e à sociabilidade familiar (Werneck, 2015, p. 201-202); e pode, evidentemente, ser o caso em que a situação chegue ao regime de violência, alocando-se na substância de competência segundo a qual as disputas são resolvidas pela força, pela imposição (Werneck, 2012).

Se não, vejamos: estamos agora em uma estação de trem de Campo Grande. No meio da plataforma, um vendedor de jornais encontrou uma solução criativa para expor o produto: com um gradeado portátil, ele fixa as capas dos principais jornais do dia, de modo que, quando parado, ele acaba por reunir em torno dele um grupo semelhante àqueles que se formam diante de bancas pela cidade. Um homem entre 50 e 60 anos - e com alguns cabelos brancos - observa algum dos jornais. De repente, para a seu lado um jovem adulto, aparentando vinte e tantos anos, e, olhando para o outro, lança o comentário:

- Ah, se tivesse um azulzinho, né, camarada!

- Como é, amigo?

- Só sacando as gostosa, né? Com um azulzinho aí, ajudava, né?

Os dois se atracam logo depois, por iniciativa do mais velho - que não seria alguém a ser considerado necessariamente "um velho". ${ }^{9} \mathrm{O}$ rapaz estava tentando chamar o outro para a brincadeira. Sem saber, chamava-o para a briga. A sugestão de necessidade de medicação para disfunção erétil (o "azulzinho", alusão ao produto mais famoso desse tipo) não foi compreendida como leve e bem-humorada pelo outro. Diferentemente, despertou nele o ímpeto de responder ao que considerou uma agressão (a sua honra) com

\footnotetext{
${ }_{9}^{9}$ Para uma discussão sobre esse reconhecimento, ver Werneck (2011).
} 
outra, com uso de força física. A situação termina com a intervenção da turma do deixa disso - aquele pessoal no entorno, conhecido ou não, que contêm os corpos e os ânimos dos envolvidos em uma briga. Os seguranças da estação chegaram a se aproximar, mas a própria gestão dos comuns abaixou a temperatura da situação. O mais velho foi embora, ainda xingando o outro. Não foi estabelecida uma paz de acordo; apenas se evitou o conflito pela evitação da interação. Mas o ingresso no regime de violência se dá sem que se tenha que passar por uma acumulação da tensão como a observável na "disputa de marra" (Werneck, 2015). No caso descrito, a deriva é oriunda do caráter (percebido pelo outro como) inoportuno e/ou desrespeitoso da zoação. Por sua dimensão de estabelecimento temporário de superioridade moral, o tênue fio entre humorização e humilhação do outro pode conduzir a um conflito aberto.

Essa informação parece integrar a regra do esporte: parte da graça da zoação está, para vários entrevistados, justamente nesse risco, nesse fio tênue entre piada e agressão. Entretanto, a coragem produzida no zoador faz parte de uma economia bastante complexa: ao mesmo tempo em que se "não [se] quer brincar, não [se] desce pro play", os atores sempre se referem à outra máxima: "Não sabe brincar, não brinca". Nesse quadro, "saber brincar" significa demonstrar competência em efetivar uma forma-piada sem que algum ruído de compreensão se apresente de modo a tornar a situação conflituosa, sem que ela se desloque na direção das competências impositivas. Trata-se, então, de uma capacidade de compreender o contexto e operar competentemente quatro elementos determinantes para aquela efetivação:

1. Quando: nem sempre se pode mobilizar a forma-crítica jocosamente, uma vez que isso pode ser inoportuno. Pode ser uma "hora ruim", um "mau momento", uma "situação inadequada" (como, digamos, fazer piada diante do sofrimento de um amigo).

2. Onde: não é em qualquer contexto, que se pode zoar. Pode não ser "o ambiente propício" (como em uma instituição seríssima), pode não ser "o lugar para isso" (como em um templo religioso), pode ser "uma área muito séria" (como quando se dialoga com a linguagem de determinadas profissões).

3. Com quem: não é qualquer pessoa que pode ser zoada, pois tanto o outro pode se sentir agredido pela zoação e responder agressivamente - como no exemplo - quanto se pode praticar uma injustiça ou uma "covardia", ao se "bater em cachorro morto" (agredindo-se alguém já submetido) ou se zoar alguém mais fraco, incapaz de se defender (uma criança, um idoso, um deficiente), ou se pode tocar em um tipo de ator considerado intocável por sua condição de "diferença” ou por 
se desrespeitar o "lugar de fala" (de gênero, de sexo, de raça, de classe etc.), sendo-se "politicamente incorreto".

4. Sobre o que: há assuntos tabu, coisas sobre as quais não se faz piada: uma grande tragédia, uma doença, uma informação pública grave etc. ${ }^{10}$

Em todos esses casos, a jocosidade percebida como inconveniente pode tornar o zoador um "otário": no Rio de Janeiro, esse termo, além de seu sentido tradicional, de indicar o tolo, o ingênuo, também pode significar alguém "sacana", que age mal e de forma covarde. Dizer: "Fulano é o maior otário" costuma querer dizer que essa pessoa atua de forma inadequada, "sem noção", em geral "na covardia". "Deixa de ser otário" também pode trazer esse sentido, indicando que o indivíduo - em vez de parvo, como poderia parecer - esteja sendo vil.

Saber brincar, assim, significa ser capaz de administrar os dispositivos mobilizados para definir a situação e a virada da forma-piada usando a formacrítica sem que se possa agredir o outro ou provocar a perda de legitimidade da própria expressão jocosa. Mas, na dependência da perspectiva, pode também significar a "falta de esportiva": "não descer para o play" pode ser uma forma de "não saber brincar". Em todo caso, como confirmamos a seguir com outros exemplos, trata-se de um conjunto de ruídos de compreensão.

\section{Compreensão falha 2: dando o maior cartaz à crítica política}

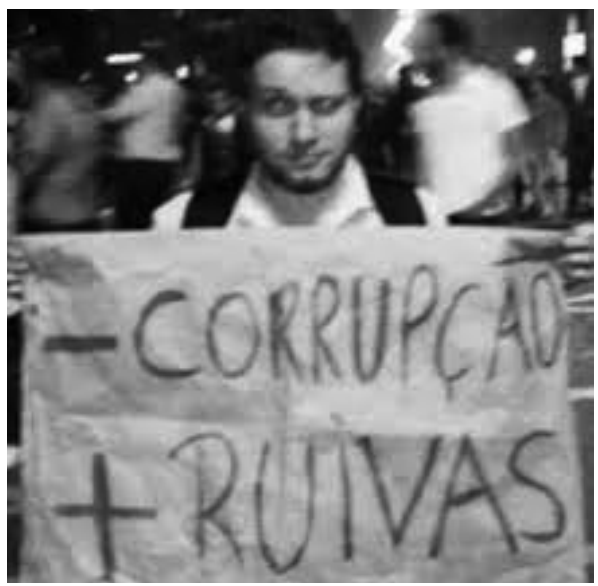

Fonte: Reprodução da internet.

\footnotetext{
${ }^{10}$ Evidentemente, todo esse protocolo depende da situação, porque haverá momentos, contextos, pessoas e assuntos que, justamente porque estão interditados em algumas situações, virarão piada em outra (a própria interdição poderá ser objeto de anedotário, aliás). Isso, sem contar a impertinência, oatode exatamentedesafiarasinterdiçõescomoformadeiconoclastiaoucríticaaelas.
} 
Essa imagem não passou despercebida em nenhuma das sessões de nossos grupos focais. Como disse, era sempre projetada para os participantes uma série de fotos exibindo cartazes levados a manifestações das "jornadas de junho". Em comum entre eles, o fato de mobilizarem formas jocosas de crítica. No caso do cartaz em questão, o ruído em geral se estabelecia de imediato, ao slide show revelar a foto: expressões faciais de desagrado, muxoxos e manifestações sonoras de crítica se seguiam. Boa parte vinha de meninas: elas recorrentemente afirmavam se tratar de uma piada sem graça. $\mathrm{O}$ motivo, o fato de ela ser "machista": colocar ruivas em oposição à corrupção seria objetificar as portadoras de cabelos vermelhos, tratá-las como "mero fetiche", e, portanto, algo inadmissível moralmente e que, por isso, não seria engraçado. A punchline é interditada porque a audiência considera que seu conteúdo, segundo ela reprovável, é incompetente para produzir uma virada de qualidade (capaz de ser engraçada) seja ela qual for. Trata-se de uma interdição moral na forma-piada e uma forma de incompreensão cujo objeto não é de nenhum modo a lógica do dispositivo jocoso. O que não se compreende ali é o quadro de referência moral adotado pelo autor - que inclui, evidentemente, o pressuposto de que seja cabível para ele fazer piada com aquilo. É preciso que se estabeleça ali uma forma de sympathy (Clark, 1998), isto é, de comunhão de formas de ver o mundo, de possibilidade de se aceitar a maneira como o outro enxerga as coisas. Pois no caso da piada, como ela constitui uma forma de ridicularização, os termos dessa redução do outro ao ridículo - porque, afinal, é entendida efetivamente como redução - precisam ser efetivadas por justificação.

Observemos o cartaz com atenção devida: ele parece recorrer a uma gramática econômica, opondo dois recursos, de um lado um excedente, a corrupção, negativizado moralmente; de outro, um recurso escasso, e portanto mais valioso, algo bonito, bom, as ruivas: faltariam ruivas (isto é, bem) em um mundo mergulhado em excesso de corruptos (isto é, mal). A crítica, então, feita de forma jocosa: há corrupção demais no Brasil. Mas para dizer isso as ruivas tiveram que ser mobilizadas como recurso, como metonímia do bem, a fim de gerar a contraposição básica da virada: onde se esperaria ver uma oposição direta entre um crime e algum bem social de mesma ordem como em um pedido do tipo "Menos corrupção, mais hospitais" - rompe-se a expectativa com um elemento da vida cotidiana, da beleza, da sexualidade, um bem deslocado em relação às políticas públicas.

Um dos detalhes da incompreensão também vem, nas palavras de algumas participantes, do fato de o bem proposto ali não ser universal (como em geral almeja a reivindicação política, mesmo que com uma pauta específica de uma 
minoria): "Mais ruivas é uma coisa boa só para os homens!", denuncia uma jovem. Outra: "E por que essa obsessão com ruivas, afinal? Por que elas seriam melhores que morenas ou louras ou negras?". Isso, somado à "misoginia" do cartaz - afinal, a fotografia mostra, carregado por um homem - impediriam que a contraposição nele proposta pudesse ser aceita como operação humorística.

Essa interdição chama atenção para outra, ainda anterior: aquela referente a se perguntar se algo "sério" como a reivindicação política poderia/deveria ser operacionalizado por algo "ridículo" como o humor. A reivindicação política e o sofrimento a que ela responde não poderiam ser maculados por um dispositivo como a piada. Por outro lado, como mostro com um colega (Werneck e Gorini, 2016), ridicularizar o oponente político pode ser para os manifestantes um dispositivo para anulá-lo como oponente e o vencer. Argumentos opostos em grupos focais distintos (mas repetidos de várias formas em todos) sintetizam o debate:

- Isso é um absurdo, não é política de verdade. Não é nem reivindicação.

- Eles [os políticos] tratam a gente como palhaço, então a resposta só pode ser na base da piada.

Pois, então. Outro cartaz não passa despercebido:

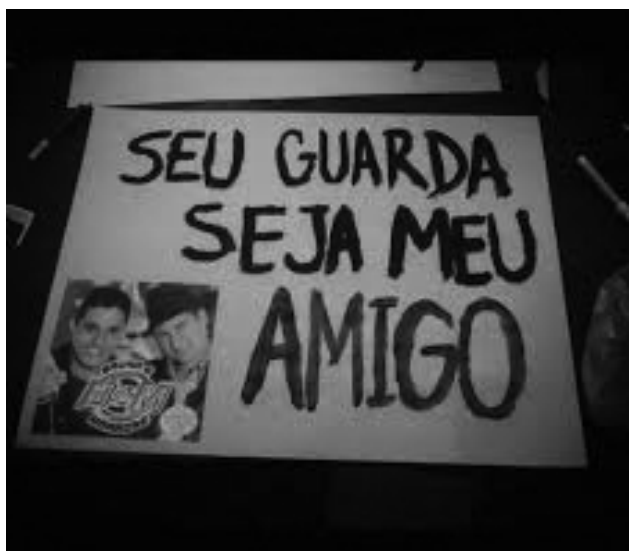

Fonte: Reprodução da internet.

Diferentemente do cartaz das ruivas, no entanto, este produz o riso imediato: quase todos entendem a piada, sentem-se contemplados por seus elementos, aceitam a questão em questão. A pergunta direta aos participantes: alguém não entendeu? A resposta, quase indignada: quem não conheceria uma das canções de maior sucesso na música brasileira recente? A citação é a 
"Dormi na praça", da dupla sertaneja Bruno e Marrone, em cuja letra o eu poético se vê ameaçado por um policial ao ser flagrado dormindo em um banco no espaço público. Em resposta, ele afirma: "Eu não sou vagabundo, não sou delinquente. Sou um cara carente". E clama: "Seu guarda, seja meu amigo, me bata, me prenda. Faça tudo comigo, mas não me deixe ficar sem ela". Deslocamento de contexto: como as manifestações foram alvo de forte reação policial e a principal pauta dos protestos acabou se tornando o próprio direito a se manifestar, dada a atuação da polícia militar, considerada por muitos violenta, o cartaz mobiliza uma forma de zoação do poder (Werneck e Gorini, 2016): ao lançar mão do pedido feito pelo eu poético, faz gracejo com a posição de força do agente da lei e da ordem. Ora, a proposta da punchline não parece ser de amizade e nem de convite ao apaziguamento da relação manifestante-PM - pelo contrário, o elemento chave da virada é justamente essa total impossibilidade, já que os "guardas" se tornaram justamente o inimigo dos manifestantes. Trata-se antes de uma agressão jocosa, de uma acusação de que o policial não está "sendo amigo", isto é, mostra-se inimigo do povo que deveria proteger. É, então, uma crítica às agressões promovidas pelas forças de segurança. ${ }^{11} \mathrm{E}$ o uso de uma canção sertaneja naquele contexto vitamina essa crítica, na medida em que leva esse agressor para o plano do ridículo, reduzindo ao absurdo suas ações - e, por conseguinte, a situação em que a distribuição de grandezas lega a ele um estado grande conquistado por meio da força, de uma imposição criticada como não legítima, incongruente com a democracia (Boltanski e Thévenot, 1991).

Mas eis que uma jovem ${ }^{12}$ ergue o braço e diz: "Eu não entendi esse aí". Todos se chocam: como é possível? Um "Só podia ser loura" brota aqui, um "Quer que desenhe?" ali (esta piada, metalinguística, recebida com muitos risos), mas o momento de zoação se encerra com a concessão da palavra à criticada para que se explique: “Quem são esses da foto? Não conheço”. A moça desconhecia Bruno e Marrone, não acompanhava sertanejo e portanto

\footnotetext{
${ }^{11}$ Entretanto, uma interpretação possível, sugerida em três dos grupos, é que o manifestante também incluía na pauta o fato de o policial ser também um trabalhador e, como tal, ser vítima dos mesmos poderosos que ele, de modo que o convite de amizade apontaria para o caráter ridículo da situação de os trabalhadores do mundo não se unirem diante de seu verdadeiro inimigo comum e para essa possibilidade de aliança.

${ }^{12}$ Embora neste exemplo tenha sido uma moça a não entender a piada, a pesquisa mostrou outras situações de incompreensão de rapazes - inclusive na crítica ao "machismo" com as ruivas. Não se trata, então, de uma marca de gênero. Por outro lado, as observações de rua mostraram ser a zoação e a disputa de marra dispositivos especialmente masculinos - embora mulheres evidentemente também mobilizem o humor em suas interações. Em outro texto, em elaboração, analiso a diferença entre a disputa de marra e o chamado "barraco", associado no campo às mulheres. Para uma discussão sobre a jocosidade e a amizade entre homens, ver Herzfeld (1985).
} 
não sabia o que poderia querer dizer a frase do cartaz. Havia um problema de inteligibilidade ali e ele não era lógico: ela não deixou de entender a piada porque esta fosse "difícil", porque houvesse nela um intricado mecanismo lógico. Nesse caso, a questão é o contexto: é porque efetivamente não comunga do mesmo universo semiológico do autor da piada e dos demais que a entenderam que a jovem não pôde compreendê-la, isto é, não pôde comungar de seu significado, pois os elementos constitutivos de sua construção não estavam disponíveis.

\section{Do 'saber brincar' ao saber entender: três formas da compreensão, dispositivo cognitivo central para a crítica}

Estamos diante, então, de uma matriz de três formas de compreensão dignas de nota quando é mobilizada a forma-crítica associada à forma-piada:

1. A piada/crítica como questão cognitiva: parece óbvio, para funcionarem, elas precisam ser entendidas. Isso quer dizer, em um primeiro plano, que se precisa fazer sentido no plano lógico para quem a elas assiste. E isso significa dizer, no caso da piada, que o mecanismo no qual se baseia a punchline (e a afirmação de negatividade moral), a virada produzida na narrativa, descrição ou enunciação, precisa ser perceptível e inteligível para o receptor. Nesse plano ainda, trata-se da competência desse receptor, mas também da legibilidade da mecânica construída. Uma piada não pode conter passos lógicos de difícil apreensão ou elementos cognitivos confusos (a menos que esse seja o elemento da própria virada). Aqui a questão e eficiência: parece haver uma verdadeira engenharia da piada, a controlar os elementos que a tornem logicamente funcional (Ermida, 2008; Watson, 2015).

2. A piada/crítica como questão contextual: para funcionarem, elas precisam falar a língua da audiência, isto é, falar de coisas que ela reconheça, com elementos que ela reconheça, mobilizando dispositivos que façam sentido para ela. A jocosidade, então, persegue "vocabulários de motivo" (Wright Mills, 1940), quadros gramaticais a guiarem sua lógica. Um contexto humorístico é uma galeria de dispositivos, todos efetiváveis por sua inteligibilidade contextual: não adianta fazer diante de um grupo de jovens uma piada mobilizando elementos da vida de idoso que eles não poderão reconhecer (Werneck e Loretti, 2016). Não adianta contar uma piada de português para um alemão, pois ele provavelmente entenderá apenas a parte lógica - um personagem faz algo estúpido -, mas não a parcela propriamente definidora da punchline (o fato de ser um patrício a praticar a "burrice"). 
3. A piada/crítica como questão moral: para funcionarem, precisam ser aprovadas como cabíveis pelo senso moral dos observadores (Billig; 2005; Kuipers, 2006; Davies, 2011). Aqui, a questão é com quem e/ou com o que se pode fazer piada - quem ou o que pode ser ridicularizado, pode ser criticado - e que elementos podem ser utilizados para esse fim. Os dispositivos contextualmente mobilizados precisariam obedecer a uma ética: determinadas "vítimas" seriam interditadas ao humorista pois elas seriam "indefesas" - a galeria varia contexto a contexto, mas é recorrente que se critiquem piadas com deficientes, gracejos de ordem racial, cultural, sexual e de gênero e problemas humanitários ou grandes sofrimentos - aqui, mais uma vez, o piadista seria o "otário", ou, na linguagem "politicamente correta", 13 o "preconceituoso". Além disso, os dispositivos mobilizados para construir a piada também precisam obedecer a critérios éticos: eles não poderiam ser elementos considerados "grosseiros" para alguém ou mesmo serem a dispositivização de um personagem interditado pela regra anterior (como no caso das ruivas do citado cartaz sobre corrupção).

Assim, as observações da crítica jocosa - e de interpretação destas pelos atores -, por sua formatação limite, permitiram mobilizar uma sociologia da compreensão para revelar a importância de seu objeto na operacionalização de críticas e prestações de contas. Compreender passa a ser entendido como uma ação social fundante, já que não se pode viver socialmente sem a inteligibilidade dos quadros de referência mobilizados pelos outros nas situações. O ponto chave aqui é a constatação do fato de a Verstenhen ser uma operação e não puramente uma faculdade cognitiva: dá trabalho compreender e a urdidura da malha das relações sociais envolve construir formas para tanto. O conjunto de operações cognitivas envolvidas nessa compreensão depende de operações sociais de inteligibilidade, de oferta e demanda de dispositivos capazes de tornar compreensíveis as situações para os envolvidos.

Esse trabalho cognitivo capaz de permitir que críticas circulem - aqui revelado por uma forma gritante, a crítica jocosa - parece estar concentrado na percepção de que toda uma fenomenologia de tradução e troca de signos - isto é, de traduções de mundos nos termos de outros mundos - se coloca como forma central de gestão do social. Como disse no começo deste texto, a adoção de uma partida compreensiva analiticamente permite perceber (mas

\footnotetext{
${ }^{13}$ Para uma história concisa e uma discussão sobre a ideia de "politicamente correto", ver Brenman (2012).
} 
também é baseada em) uma partida compreensiva na própria administração das situações. Trata-se, então, de uma accountability social revelada em sua dimensão semiológica: manifestar as insatisfações e demandar mudanças assim como efetivar as situações criticadas, delas prestando contas - é uma operação moral dependente dessa complexa operação aqui descortinada, a compreensão.

\section{Referências}

AUSTIN, John L. How to do things with words. Boston: Harvard University Press, 1975.

AUSTIN, John L. A plea for excuses. In: Philosophical papers. Londres: Oxford University Press, 1979 [1956-1957]. p. 175-204 <10.1093/019283021X.003.0008>.

BILLIG, Michael. Laughter and ridicule: towards a social critique of humour. Londres: Sage, 2005.

BOLTANSKI, Luc. L'amour et la justice comme compétences: trois essais de sociologie de l'action. Paris: Métailié, $1990<10.3917 /$ meta.bolta.1990.01>.

BOLTANSKI, Luc. De la critique: précis de sociologie de l'émancipation. Paris: Gallimard, 2009.

BOLTANSKI, Luc; THÉVENOT, Laurent. De la justification: les économies de la grandeur. Paris: Gallimard, 1991.

BOLTANSKI, Luc; THÉVENOT, Laurent. The sociology of critical capacity. European Journal of Social Theory, v. 2, n. 3, p. 359-377, 1999<10.1177/136843199002003010>.

BRENMAN, Ilan. A condenação de Emilia: o politicamente correto na literatura infantil. Belo Horizonte: Aletria, 2012.

CARDOSO DE OLIVEIRA, Luis Roberto. Concretude simbólica e descrição etnográfica (sobre a relação entre antropologia e filosofia). In: Alexandre Werneck; Luis Roberto Cardoso de Oliveira (orgs.). Pensando bem: estudos de sociologia e antropologia da moral. Rio de Janeiro: Casa da Palavra, 2014. p. 49-77.

CARTER, Judy. The comedy bible: from stand-up to sitcom - the comedy writer's ultimate 'how to' guide. Nova York: Touchstone, 2001.

CICOUREL, Aaron V. Method and measurement in sociology. Nova York: The Free Press, 1964.

CLARK, Candace. Misery and company: sympathy in everyday life. Chicago: University of Chicago Press, 1998.

COLEBROOK, Claire. Irony. Londres e Nova York: Routledge, 2004.

COLLINS, Randall. On the micro-foundations of macro-sociology. American Journal of Sociology, n. 86, p. 984-1014, 1981.

COMERFORD, John Cunha. Fazendo a luta: sociabilidade, falas e rituais na construção de organizações camponesas. Rio de Janeiro: Relume Dumará, 1999. 
DAVIES, Christie. Jokes and targets. Bloomington: Indiana University Presss, 2011. ERMIDA, Isabel. The language of comic narratives: humor construction in short stories. Berlim e Nova York: Mouton de Gruyter, 2008 < 10.1515/9783110208337>.

GARFINKEL, Harold. Studies in Ethnometodology. Englewood Cliffs: The Free Press, 1967.

GOFFMAN, Erving. Relations in public: microstudies of the public order. Nova York: Basic Books, 1971.

GOHN, Maria da Glória. Manifestações de junho de 2013 no Brasil e praças dos indignados no mundo. Petrópolis: Vozes, 2014.

GREIMAS, Algirdas J. Semantique structurale: recherche de methode. Paris, Larousse, 1966.

HERZFELD, Michael. Irony and power: toward a politics of mockery in Greece. In: The poetics of Manhood: contest and identity in a Cretan Mountain Village. Princeton: Princeton University Press, 1985.

HUTCHEON, Linda. Irony's Edge: The theory and politics of irony. Nova York: Routledge, 1995.

JOAS, Hans. The creativity of action. Chicago: The University of Chicago Press, 1996.

JOSEPH, Isaac. Le passant considérable. Paris: Librairie des Méridiens, 1984.

KAPLAN, Steve. The hidden tools of comedy: the serious business of being funny. Los Angeles: Michael Wiese Productions, 2013.

KNORR-CETINA, Karin. The micro-sociological change of the macro-sociology: towards a reconstruction of social theory and methodology. In: Karin Knorr-Cetina; Aaron V. Cicourel (orgs.). Advances in social theory and methodology: toward an integration of micro- and macro-sociologies. Boston e Londres: Routledge/Keegan Paul, 1981. p. 1-47.

KUIPERS, Giselinde. Good humor, bad taste: a sociology of the joke. Berlim e Nova York: Mouton de Gruyter, $2006<10.1515 / 9783110898996>$.

LATOUR, Bruno. Ciência em ação: como seguir cientistas e engenheiros sociedade afora. São Paulo: Unesp, 1997 [1987].

MCEVOY, Sebastian. L'invention défensive: poétique, linguistique, droit. Paris: Métailié, 1995.

MISSE, Michel; WERNECK, Alexandre. O interesse no conflito. In: Michel Misse e Alexandre Werneck (orgs.). Conflitos de (grande) interesse: estudos sobre crimes, violências e outras disputas conflituosas. Rio de Janeiro: Garamond, 2012. p. 7-25.

PELZ, Werner. The scope of understanding in Sociology. Londres: Routledge, 1974.

PEIRCE, Charles S. The essential Peirce: selected philosophical writings (18931913). 2. v. Bloomington: Indiana University Press, 1998 [1893].

RASKIN, Victor (org.). The primer of humor research. Berlim e Nova York: Mouton de Gruyter, 2008. 
RITZER, George; GINDOFF, Pamela. Agency-structure, micro-macro, individualismholism-relativism: a metatheoretical explanation of theoretical convergence between the United States and Europe. In: Piotr Sztompka (org.). Agency and structure: reorienting social theory. Londres: Routledge, 2014. p. 3-24.

SCOTT, Marvin B.; LYMAN, Stanford M. “Accounts". Dilemas: Revista de Estudos de Conflito e Controle Social, v. 1, n. 2, 2008 [1968], p. 139-172.

SZTOMPKA, Piotr. Evolving focus on human agency in contemporary social theory. In: Piotr Sztompka (org.). Agency and structure: reorienting social theory. Londres: Routledge, 2014. p. 25-60.

THÉVENOT, Laurent.. L'action qui convient. In: Patrick Pharo e Louis Quéré. Les formes de l'action: sémantique et sociologie. Paris: Éditions de l'EHESS, 1990. p. 39-69.

THOMAS, William I. Unadjusted girl: with cases and standpoint for behavior analysis. Nova York: Patterson Smith, 1969 [1923].

THOMAS, William I.; THOMAS, Dorothy Swaine. The child in America: behavior problems and programs. Nova York: A. A. Knopf, 1938 [1928].

VORHAUS, John. The comic toolbox: how to be funny even if you're not. Los Angeles: Silman-James, 1994.

WATSON, Cate. A sociologist walks into a bar (and other academic challenges): towards a methodology of humour. Sociology, v. 49, n. 3, p. 407-421, $2015<10.1177$ / 0038038513516694>.

WEBER, Max. “A 'objetividade' do conhecimento na Ciência Social e na Ciência Política”, in: Metodologia das Ciências Sociais. São Paulo: Cortez, 2001 [1904]. p. 107-154.

WEBER, Max. The theory of social and economic organization. Glencoe: The free Press, 1947 [1922].

WERNECK, Alexandre. A velhice como competência de efetivação de ações moralmente questionadas: situações em supermercados no Rio de Janeiro. Revista Brasileira de Sociologia da Emoção, v. 10, n. 28, p. 10-44, 2011.

WERNECK, Alexandre. A desculpa: as circunstâncias e a moral das relações sociais. Rio de Janeiro: Civilização Brasileira, 2012.

WERNECK, Alexandre. Sociologia da moral, agência social e criatividade. In: Alexandre Werneck e Luís Roberto Cardoso de Oliveira (orgs.). Pensando bem: estudos de sociologia e antropologia da moral. Rio de Janeiro: Casa da Palavra, 2014. p. 25-48.

WERNECK, Alexandre. Dar uma zoada, botar a maior marra: dispositivos morais de jocosidade como formas de efetivação e sua relação com a crítica. Dados: Revista de Ciências Sociais, v. 58, n. 1, p. 187-222, $2015<10.1590 / 00115258201542>$.

WERNECK, Alexandre; GORINI, Gabriel. Dispositivos morais de jocosidade como moduladores da crítica: um estudo sobre o humor nos cartazes de manifestações. In: Alexandre Werneck (org.). Violências moduladas: gramáticas e dispositivos da crítica e da negociação na conflitualidade urbana no Rio de Janeiro. Relatório de pesquisa, Faperj, 2016. 
WERNECK, Alexandre; LORETTI, Pricila. Forma-crítica, formas da crítica: um estudo do papel das diferentes dimensões do discurso crítico em sua efetivação. Trabalho apresentado no I Colóquio Crítica e pragmatismo na sociologia: Diálogos entre Brasil e França. Brasília, UnB, 2016.

WRIGHT MILLS, Charles. Situated actions and vocabularies of motive. American Sociological Review, v. 5, n. 6, p. 904-913, $1940<10.2307 / 2084524>$.

Autor correspondente:

Alexandre Werneck

Instituto de Filosofia e Ciências Sociais, UFRJ

Largo de São Francisco de Paula, 1, Sala 405 - Centro

20051-070 Rio de Janeiro, RJ, Brasil

Recebido em: 22 set. 2015

Aprovado em: 31 ago. 2016 